\title{
Expression of Matrix Metalloproteinase-1 in Human Colorectal Carcinoma
}

Junichi Shiozawa, M.D., Masahiro Ito, M.D., Toshiyuki Nakayama, M.D., Masahiro Nakashima, M.D., Shigeru Kohno, M.D., Ichiro Sekine, M.D.

Department of Molecular Pathology (JS, MI, TN, IS), Division of Scientific Data Registry (MN) and Second Department of Internal Medicine (SK), Nagasaki University School of Medicine, Nagasaki, Japan

Matrix metalloproteinases are considered to play an important role in tumor invasion and metastasis. To elucidate the involvement of MMP-1 in human colorectal carcinoma, we performed immunohistochemical analysis on tissues from 20 colorectal adenomas and 142 colorectal adenocarcinomas, including 27 intramucosal carcinomas and 115 invasive carcinomas. MMP-1 was not expressed in any of the 20 cases of colorectal adenoma examined. In contrast, 108 of 142 cases $(76.1 \%)$ with colorectal adenocarcinoma showed immunoreactivity for MMP-1 in the carcinoma cells themselves. Expression of MMP-1 was also identified in stromal cells around the carcinoma. We investigated the relationship between pathological features in colorectal carcinoma and MMP-1 immunoreactivity of the tumor cells. MMP-1 expression was less frequent in intramucosal carcinomas and weaker than that in invasive carcinomas $(P<.0001)$. Among the 115 cases of invasive carcinomas, MMP-1 immunoreactivity was significantly correlated with the depth grading of tumor invasion $(P<.05)$, tumor growth pattern $(P<.05)$, the presence of lymphatic invasion $(P<.05)$, venous invasion $(P<.05)$, neural invasion $(P<.05)$, lymph node metastasis $(P<$ $.005)$, hepatic metastasis $(P<.05)$, and increasing stages of Dukes' classification $(P<.05)$. In situ hybridization, using an $M M P-1$ oligonucleotide probe, confirmed the presence of MMP-1 mRNA in colorectal carcinoma cells themselves. Expression of MMP-1 mRNA was detected by the reverse transcription polymerase chain reaction method in cultured human colorectal carcinoma cell lines and colon carcinoma tissue obtained at surgery. These findings suggest that the expression of MMP-1 is

Copyright () 2000 by The United States and Canadian Academy of Pathology, Inc.

VOL. 13, NO. 9, P. 925, 2000 Printed in the U.S.A.

Date of acceptance: April 6, 2000.

Address reprint requests to: Junichi Shiozawa, M.D., Department of Molecular Pathology, Nagasaki University School of Medicine, 1-12-4 Sakamoto, Nagasaki 852-8523, Japan; e-mail address: m-ito@net.nagasakiu.ac.jp; fax: 81-95-849-7108. one of the important factors related to tumor invasion and metastasis in colorectal carcinoma.

KEY WORDS: Colorectal carcinoma, Immunohistochemistry, Invasion, Metastasis, MMP-1.

Mod Pathol 2000;13(9):925-933

Colorectal carcinoma is the most common malignant tumor of the alimentary tract in the Western world. At the time of diagnosis, colorectal carcinoma usually shows extensive local invasion and metastasis. Enzymatic degradation of the extracellular matrix, such as basement membrane and interstitial stroma, is an essential step in tumor invasion and metastasis (1). Matrix metalloproteinases (MMPs) constitute a family of zinc-dependent enzymes that are involved in the degradation of the extracellular matrix (2). According to their structures and substrate specificities, MMPs can be classified into subgroups of collagenases (MMP-1, MMP-8, and MMP-13), gelatinases (MMP-2 and MMP-9), stromelysins (MMP-3, MMP-10, MMP-12, and MMP-7), membrane-type MMPs (MT-MMPs) and other MMPs. Currently, this family of MMPs has at least 17 different members (3).

Tumor invasion is facilitated by degradation of the interstitial stroma, which is the main component of the extracellular matrix. This process can be furthered by collagenases, particularly interstitial collagenase (MMP-1) (4). A requirement for MMP-1 for tumor invasion has been demonstrated in in vitro assays (5). However, the tissue distribution and the role of MMP-1 in vivo are still controversial. Previously, MMP-1 was shown to be expressed mainly in stromal cells surrounding the carcinoma cells (6-9). In contrast, recent studies have reported MMP-1 expression by the carcinoma cells themselves and suggested a relationship between tumor progression and this MMP-1 expression (10-13). Murray et al. (11) have described that immunohistochemically detected MMP-1 expression by the tumor cells was associated with poor prognosis of patients with colorectal carcinoma. However, thus 
far there has been no comparative study on MMP-1 expression by tumor cells in colorectal cancer compared with the pathologic features.

Based on the findings of Murray et al. (11), we hypothesized that colorectal carcinoma cells may be capable of MMP-1 production and that its expression by the carcinoma cells themselves may be involved in the progression of the cancer. The aim of the present study, therefore, is to elucidate the clinicopathologic role of immunohistochemically detected MMP-1 expression in cancer cells in the progression of colorectal carcinoma, especially in local invasion and metastasis.

\section{MATERIALS AND METHODS}

We studied 20 cases of colorectal adenoma and 142 cases of primary human colorectal carcinoma by immunohistochemistry. All tumors were obtained from patients who had undergone surgery or endoscopic resection at Nagasaki University Hospital between 1996 and 1998. Fifteen specimens of normal colorectal tissue were evaluated as normal controls.

Each tumor was assigned a histologic type according to the World Health Organization classification as follows: well differentiated adenocarcinoma (comprised of well-formed glands in which the nuclei are uniform in size and shape and retain a basal location), moderately differentiated adenocarcinoma (glands are less regular but remain easily recognizable and nuclei are large and lack a basal location), and poorly differentiated adenocarcinoma (cells are arranged in irregular clusters, with little evidence of glandular differentiation) (14).

According to the TNM staging system of the American Joint Commission on Cancer, the depth grading of tumor invasion in each of the carcinomas was classified into five groups as follows: Tis (carcinoma in situ or limited to mucosa), T1 (invading submucosa), T2 (invading muscularis propria), T3 (invading either subserosa or pericolic tissue), and T4 (through serosa or invading contiguous organs) (15). Tumor growth pattern was assessed as "expanding" (advancement of tumor occurred with a bulbous circumscribed pushing border) and "infiltrative" (tumor dissected sharply through the bowel wall) (16).

The desmoplastic stromal reaction was graded according to the extent of the stromal area involved. It was defined as "slight" (when the fibrous stromal area was less than $25 \%$ of the whole tumor), "moderate" (between 25 and 50\%), and "extensive" (when it exceeded $75 \%$ of the whole tumor) based on the overall pattern (16). The Crohn's-like lymphoid reaction was defined as lymphoid aggregates, often with germinal centers, ringing the periphery of invasive carcinoma (17). It was assessed as "conspicuous" (when multiple large lymphoid aggregates occurred) or "inconspicuous" (when no lymphoid aggregates were present or occasional small lymphoid aggregates were identified).

The examination was performed on routine slides to identify lymphatic, venous, and neural invasion. In addition to hematoxylin and eosin staining, we also used elastic van Gieson stain in all cases. Each parameter was defined as "present" when invasion was identified with certainty, but defined as "absent" when either not observed at all or not observed with certainty $(18,19)$.

Lymph node metastasis was defined as "positive" only when histologically proven; hepatic metastasis was defined as "positive" when it was either histologically or clinically proven.

Based on Dukes' classification, pathological stages of colorectal carcinoma were classified into five groups as follows: A (tumor invading submucosa or muscularis propria), B (tumor extending beyond muscularis propria), $\mathrm{Cl}$ (with positive regional lymph nodes only), C2 (with a positive apical node), and D (with distant metastasis) $(20,21)$. Diagnosis was established by two independent pathologists (JS, MI), and cases of questionable diagnosis were omitted from the study.

\section{Immunohistochemistry}

Formalin-fixed and paraffin-embedded tissues were cut into $4-\mu \mathrm{m}$ sections, deparaffinized in xylene, and rehydrated in phosphate-buffered saline. The deparaffinized sections were preincubated with normal bovine serum to prevent nonspecific binding, and then incubated overnight at $4^{\circ} \mathrm{C}$ with an optimal dilution $(0.5 \mu \mathrm{g} / \mathrm{mL})$ of a primary monoclonal antibody against human MMP-1 (F-67, Fuji Chemical Industries, Ltd., Toyama, Japan) (22). Thereafter, the slides were incubated with an alkaline phosphatase-conjugated goat anti-mouse immunoglobulin antibody. The reaction products were resolved using a mixture of 5-bromo-4-chloro3-indolyl phosphate and nitroblue tetrazolium chloride (BCIP/NBT; DAKO, Carpinteria, CA). Rheumatoid arthritis tissue served as the positive control (22). Analysis of immunohistochemical staining was performed by two investigators (JS, MI). MMP-1 expression was classified into three categories, depending on the percentage of cells stained: 0 to $10 \%$ positive cells were considered negative (-), 11 to $50 \%$ positive cells, weak positive $(+)$; and more than $50 \%$ positive cells strong positive $(++)$.

\section{In Situ Hybridization}

In situ hybridization for the detection of $M M P-1$ mRNA was performed using an oligonucleotide 
probe complementary to a fragment of human MMP-1 mRNA (23). The sequence of the oligonucleotide probe is $5^{\prime}$-CTCAACTTCCGGGTAGAAGGGATTTGTGCGCATGTAGAATCTGTC-3'. This sequence does not cross-hybridize with other known sequences, including mRNA for other types of $M M P s$. The probe was labeled with $3^{\prime}$ tailed digoxigenin and purified by high performance liquid chromatography (Greiner Japan, Inc., Tokyo, Japan). Twenty cases of human colorectal adenocarcinoma and six cases of adenoma were studied. In all of these cases, we were able to obtain relatively fresh (within $6 \mathrm{mo}$ ) formalin-fixed and paraffinembedded sections. Prehybridization was carried out as described previously (24). The sections were treated with $0.2 \mathrm{~N} \mathrm{HCl}$ for $20 \mathrm{~min}$ and digested with $10 \mu \mathrm{g} / \mathrm{mL}$ of proteinase K (Sigma, St. Louis, MO) for $15 \mathrm{~min}$ at $37^{\circ} \mathrm{C}$. After postfixation in $4 \%$ paraformaldehyde, each section was covered with $20 \mu \mathrm{L}$ of denatured hybridization mixture containing $8 \%$ dextran sulfate, $125 \mu \mathrm{g} / \mathrm{mL}$ sonicated salmon sperm DNA, $40 \%$ deionized formamide, $250 \mu \mathrm{g} / \mathrm{mL}$ yeast tRNA, $1 \times$ Denhardt's solution, $1 \mathrm{~mm}$ EDTA (ethylenediamine-tetra-acetic acid, $\mathrm{pH}$ 7.4), $0.6 \mathrm{M}$ $\mathrm{NaCl}, 10 \mathrm{~mm}$ Tris- $\mathrm{HCl}$, and $2 \mu \mathrm{g} / \mathrm{mL}$ digoxigeninlabeled $M M P-1$ oligonucleotide probe, and placed in a moist chamber, where it was incubated at $37^{\circ} \mathrm{C}$ for 15 hours. After hybridization, slides were washed three times in $40 \%$ formamide in $2 \times$ SSC at $37^{\circ} \mathrm{C}$ for 1 hour each. Briefly, the slides were incubated with $150 \mu \mathrm{L}$ of blocking solution for $30 \mathrm{~min}$ at room temperature and incubated with antidigoxigenin-alkaline phosphatase Fab fragments (Boehringer Mannheim, Mannheim, Germany). MMP-1 mRNA expression was evaluated by comparing alkaline phosphatase staining using BCIP/ NBT with the results obtained from the negative and positive controls. Consecutive sections were reacted with the digoxigenin-labeled sense oligonucleotide probe (5'-GACAGATTCTACATGCGCACAAATCCCTTCTACCCGGAAGTTGAG-3') and with the non-probe solution (hybridization solution without probes) as negative controls. RNase treatment was carried out before hybridization as another negative control. The presence of cytoplasmic RNA was confirmed through the use of a methyl green pyronine staining solution (Muto Pure Chemicals, Tokyo, Japan). In order to assess RNA integrity and the hybridizability of each specimen, in situ hybridization using an oligonucleotide probe complementary to a fragment of human 28S ribosome RNA (antisense; 5' -TGCTACTACCACCAAGATCTGCACCTGCGGCGGC3', sense; 5'-GCCGCCGCAGGTGCAGATCTTGGTGGTAGTAGCA-3') was also routinely performed with consecutive sections as a technical positive control (25). Slides of a rheumatoid arthritis tissue served as a tissue positive control (26).

\section{Reverse Transcription (RT)-PCR}

Total RNA was prepared from three human colorectal carcinoma cell lines (LoVo, SW837, and DLD$1)$, two cases of colon cancer tissue, one case of colon adenoma tissue, and two cases of normal colon mucosa, using the acid/guanidine/phenol method (27).

Three human colorectal carcinoma cell lines, LoVo (poorly differentiated adenocarcinoma), SW837 (adenocarcinoma), and DLD-1 (adenocarcinoma) were incubated at $37^{\circ} \mathrm{C}$ in a humidified atmosphere of $5 \% \mathrm{CO}_{2}$ and $95 \%$ air (28-30). Cultures of LoVo were maintained in RPMI medium 1640 (Life Technologies, Grand Island, NY) supplemented with $10 \%$ fetal calf serum (28). SW837 was maintained in modified L-15 medium with $10 \%$ fetal calf serum (29) and DLD-1 was maintained in DMEM/F-12 (Life Technologies) supplemented with $10 \%$ fetal calf serum (30). Plastic culture dishes were purchased from Beckton Dickinson (Oxnard, CA). All of these cells were provided by the Health Science Research Resources Bank (Osaka, Japan).

Cellular RNA $(1 \mu \mathrm{g})$ was incubated at $37^{\circ} \mathrm{C}$ for 1 hour in $50 \mu \mathrm{L}$ of reverse transcriptase (RT) buffer containing 20 units of RNAsin (Promega Corp., Madison, WI), $100 \mathrm{pm}$ of random hexamer primers (Boehringer Mannheim), and 400 units of Moloney murine leukemia virus reverse transcriptase (Life Technologies). RT was terminated by heating at $95^{\circ}$ $\mathrm{C}$ for $10 \mathrm{~min}$, and $20 \%$ of the resultant cDNA was removed for polymerase chain reaction (PCR). PCR-RT samples were incubated with $50 \mathrm{pm}$ of each primer and 2.5 units of Taq DNA polymerase. The human $M M P-1$ PCR primers were $5^{\prime}$ TTCATTTCTGTTTTCTGGCC-3' (sense) and $5^{\prime}$ ATTTTTCCTGCAGTTGAACC-3' (antisense) (31). The human $\beta$-actin PCR primers were $5^{\prime}$-TCCTCCCTGGAGAAGACTA-3' (sense) and 5'-AGTACTTGCGCTCAGGAGGA-3' (antisense). The MMP-1 and $\beta$-actin primers were predicted to amplify 462 and 313 bp DNA fragments, respectively. Each primer pair was chosen to span the introns of their respective human genes. Samples were subjected to 35 cycles of PCR amplification using a thermocycler. Each cycle included denaturation at $94^{\circ} \mathrm{C}$ for $1 \mathrm{~min}$, annealing at $52^{\circ} \mathrm{C}$ for $1.5 \mathrm{~min}$, and primer extension at $72^{\circ} \mathrm{C}$ for 1 min. An aliquot of each amplification mixture was subjected to electrophoresis on a $1.5 \%$ agarose gel, and DNA was visualized by ethidium bromide staining.

\section{Statistical Analysis}

The Stat View computer program (ABACUS Concepts Inc., Berkeley, CA) was used for statistical analyses. Analyses comparing expression of MMP-1 by immunoreactivity with each factor examined 
were performed by Mann-Whitney's $U$ test or the Kruskal-Wallis test.

\section{RESULTS}

Of the 142 patients with colorectal carcinoma, 82 were male and 60 were female. The median age was 67.3 years (range, 39 to 87). Fifty-one tumors were located in the rectum, 41 in the sigmoid colon, 8 in the descending colon, 11 in the transverse colon, 25 in the ascending colon, and six in the cecum. Histologically, there were 27 intramucosal carcinomas and 115 invasive carcinomas. All 27 cases of in- tramucosal carcinoma were well-differentiated adenocarcinomas (data not shown). Of the 115 invasive carcinomas, 48 were well-differentiated adenocarcinomas, 51 were moderately differentiated adenocarcinomas, and 16 were poorly differentiated adenocarcinomas. Among the invasive carcinomas, there were 28 cases of T1 tumor, 21 cases of T2 tumor, 60 cases of T3 tumor, and six cases of T4 tumor. Forty-seven cases had lymph node metastasis and 21 cases had distant metastasis (14 cases had hepatic metastasis and seven cases had metastasis to other organs).

Figure 1 shows representative examples of strong
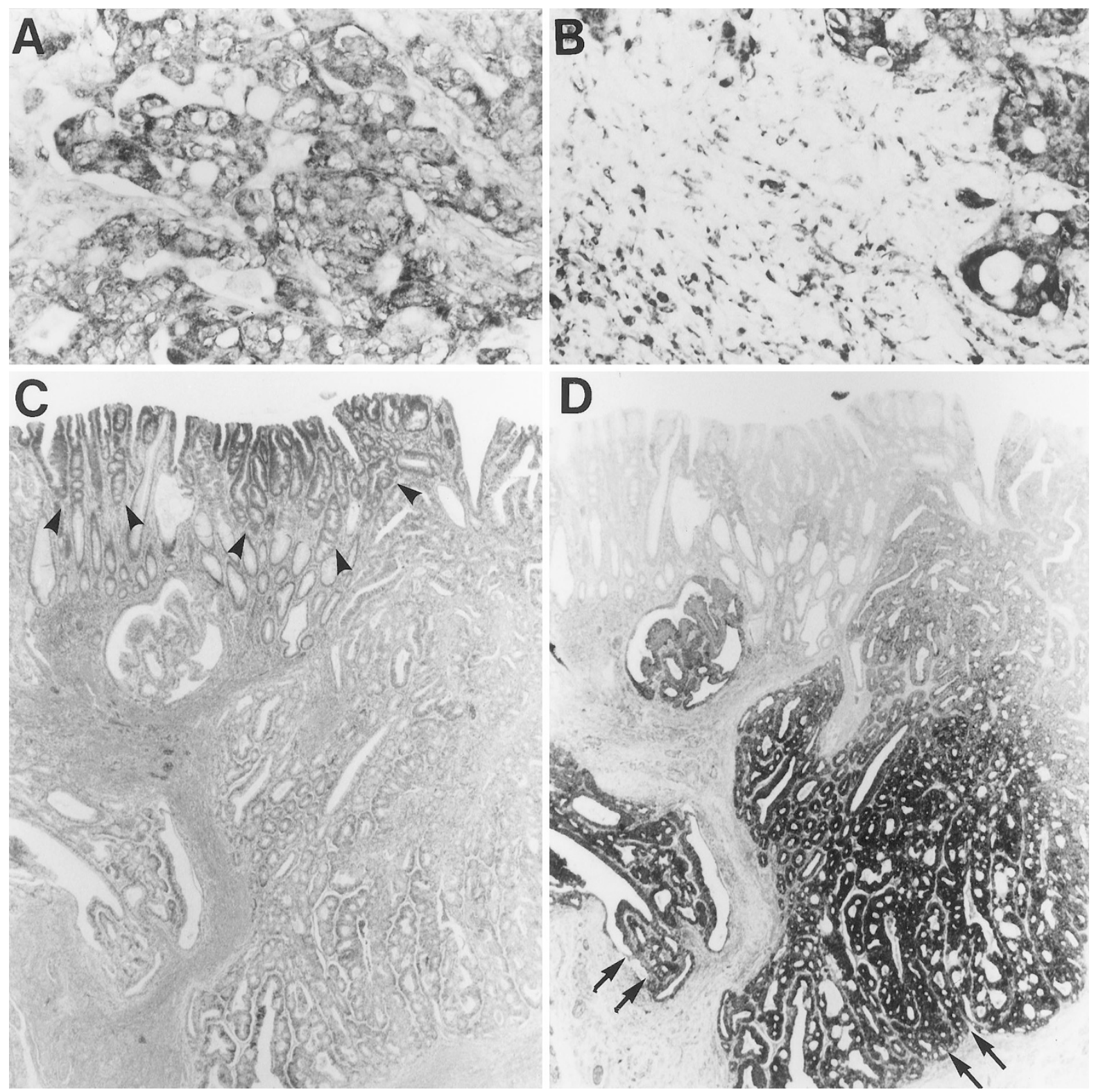

FIGURE 1. Immunohistochemistry of MMP-1 in colorectal adenocarcinomas. MMP-1 is strongly expressed in the cytoplasm of tumor cells (A) (immunoalkaline phosphatase stain; original magnification, 50×). Expression of MMP-1 was also identified in stromal cells around the tumor cells (B) (immunoalkaline phosphatase stain; original magnification, 50×). Hematoxylin-eosin staining of submucosal invasive carcinoma with adenoma (arrowheads) (C) (original magnification, $5 \times$ ). MMP-1 expression is positive in the area of carcinoma but negative in the area of adenoma. The intensity of MMP-1 expression in the deep part of invasion (arrows) was stronger than that in the superficial part (D) (immunoalkaline phosphatase stain; original magnification, $5 \times$ ). 
immunohistochemical MMP-1 staining in colorectal carcinomas. MMP-1 protein stained in the cytoplasm of the carcinoma cells (Fig. 1A). Expression of MMP-1 was also identified in stromal cells (i.e., fibroblasts, inflammatory cells, endothelial cells) around the tumor (Fig. 1B). Of the 142 colorectal carcinomas, 40 cases (23 intramucosal carcinoma and 17 invasive carcinoma) contained various amounts of adenoma (so called adenocarcinoma in/with adenoma), and in those cases, MMP-1 expression was restricted to the area of adenocarcinoma (Fig. 1, C-D). In many cases, the invasive front and the peripheral parts of the carcinoma were intensely stained compared with the superficial and central parts (Fig. 1D).

Table 1 shows MMP-1 immunoreactivity of tumor cells in human colorectal neoplasms. MMP-1 was not expressed in any of the 15 cases of normal colorectal epithelium studied, nor in any of the 20 cases of colorectal adenoma. In contrast, 108 of 142 cases $(76.1 \%)$ with colorectal adenocarcinoma showed immunoreactivity for MMP-1 in the carcinoma cells themselves. The immunoreactivity was weak in all cases of intramucosal carcinoma, whereas strong immunoreactions were found in $52.2 \%(60 / 115)$ of invasive carcinomas. Statistical analysis showed a significant difference between intramucosal carcinomas and invasive carcinomas $(P<.0001)$.

The relationships between MMP-1 immunoreactivity of the tumor cells and pathological features in invasive carcinomas are summarized in Table 2. MMP-1 expression was found in $77.1 \%$ (37/48) of well-differentiated adenocarcinomas, $\quad 92.2 \%$ (47/51) of moderately differentiated adenocarcinomas, and $87.5 \%(14 / 16)$ of poorly differentiated adenocarcinomas. There were no significant associations between MMP-1 immunoreactivity and the differentiation stage of colorectal adenocarcinomas.

MMP-1 immunoreactivity was compared with the depth grading of tumor invasion and tumor growth pattern. MMP-1 expression was found in $71.4 \%(20 / 28)$ of $\mathrm{T} 1$ tumor, in $85.7 \%(18 / 21)$ of $\mathrm{T} 2$

TABLE 1. MMP-1 Immunoreactivity of Tumors Cells in Human Colorectal Neoplasm

\begin{tabular}{|c|c|c|c|c|}
\hline & \multirow{2}{*}{$n$} & \multicolumn{3}{|c|}{ MMP-1 Immunoreactivity ${ }^{a}$} \\
\hline & & - & + & ++ \\
\hline Adenocarcinoma & 142 & $34(23.9 \%)$ & $48(33.8 \%)$ & $60(42.3 \%)$ \\
\hline $\begin{array}{l}\text { Intramucosal carcinoma } \\
\text { (Tis) }\end{array}$ & 27 & $17(63.0 \%)$ & $10(37.0 \%)$ & $0(0.0 \%)^{b}$ \\
\hline $\begin{array}{l}\text { Invasive carcinoma } \\
\quad(\mathrm{T} 1-\mathrm{T} 4)\end{array}$ & 115 & $17(14.8 \%)$ & $38(33.0 \%)$ & $60(52.2 \%)^{b}$ \\
\hline Adenoma & 20 & $20(100 \%)$ & $0(0.0 \%)$ & $0(0.0 \%)$ \\
\hline Normal epithelium & 15 & $15(100 \%)$ & $0(0.0 \%)$ & $0(0.0 \%)$ \\
\hline
\end{tabular}

${ }^{a}$ See Material and Methods for classification of staining intensity.

${ }^{b} P<.0001$; Mann-Whitney's $U$ test. tumor, in $90.0 \%(54 / 60)$ of T3 tumor, and in $100 \%$ (6/6) of T4 tumor, respectively. A significant correlation was found between MMP-1 immunoreactivity and the depth grading of tumor invasion $(P<$ .05). Furthermore, the degree of MMP-1 expression was higher in the cases showing an infiltrative growth pattern than the cases showing an expansive pattern $(P<.05)$.

The relationship between MMP-1 immunoreactivity of the tumor cells and the stromal reactions (desmoplastic stromal reaction and Crohn's-like lymphoid reaction) were investigated. There were no significant associations between MMP-1 immunoreactivity and such parameters.

The incidence of lymphatic invasion, venous invasion, and neural invasion was $46.1 \%, 35.7 \%$ and $19.1 \%$, respectively. MMP-1 immunoreactivity was significantly correlated with the presence of lymphatic invasion $(P<.05)$, venous invasion $(P<.05)$, and neural invasion $(P<.05)$.

Immunoreactivity in the primary site of colorectal carcinomas was significantly correlated with the presence of lymph node metastasis $(P<.005)$ and hepatic metastasis $(P<.05)$. Immunoreactivity for MMP-1 was also correlated with increasing stages of Dukes' classification $(P<.05)$.

$M M P-1$ mRNA expression was detected in the cytoplasm of carcinoma cells by in situ hybridization (Fig. 2A). MMP-1 mRNA was also identified in stromal cells. No specific hybridization was observed with the sense labeled probe and the nonprobe solution (Fig 2B). RNase treatment of the sections hybridized with the $M M P-1$ oligonucleotide probe yielded no positive signals. $M M P-1$ mRNA was not detected in the sections of adenoma (Fig. 2C), whereas expression of $28 \mathrm{~S}$ ribosome RNA, as a technical positive control, could be observed in consecutive sections (Fig. 2D).

The results from RT-PCR analysis of $M M P-1$ mRNA expression in normal colon mucosa, adenoma, adenocarcinoma tissues and human colorectal carcinoma cell lines are shown in Figure 3. MMP-1 mRNA was not detected in normal colon mucosa or adenoma, whereas strong expression of $M M P-1$ mRNA was observed in the colon carcinoma tissues and two of three human colorectal carcinoma cell lines. $\beta$-actin mRNA, a control to demonstrate that equivalent amounts of tissue RNA were used for cDNA synthesis, was detected in all samples.

\section{DISCUSSION}

Prognosis in patients with colorectal carcinoma has conventionally been determined by a staging system based on the extent of primary tumor and the presence or absence of metastasis, as in Dukes' 


\begin{tabular}{|c|c|c|c|c|c|}
\hline \multirow{2}{*}{ Pathological Features } & & \multirow{2}{*}{$n$} & \multicolumn{3}{|c|}{ MMP-1 Immunoreactivity } \\
\hline & & & - & + & ++ \\
\hline \multirow[t]{3}{*}{ Differentiation } & Well & 48 & $11(22.9 \%)$ & $17(35.4 \%)$ & $20(41.7 \%)$ \\
\hline & Moderate & 51 & $4(7.8 \%)$ & $18(35.3 \%)$ & $29(56.9 \%)$ \\
\hline & Poor & 16 & $2(12.5 \%)$ & $3(18.8 \%)$ & $11(68.8 \%)$ \\
\hline \multirow[t]{4}{*}{ Depth of tumor invasion ${ }^{a}$} & $\mathrm{~T} 1$ & 28 & $8(28.6 \%)$ & $10(35.7 \%)$ & $10(35.7 \%)$ \\
\hline & $\mathrm{T} 2$ & 21 & $3(14.3 \%)$ & $10(47.6 \%)$ & $8(38.1 \%)$ \\
\hline & T3 & 60 & $6(10.0 \%)$ & $16(26.7 \%)$ & $38(63.3 \%)$ \\
\hline & $\mathrm{T} 4$ & 6 & $0(0.0 \%)$ & $2(33.3 \%)$ & $4(66.7 \%)$ \\
\hline \multirow[t]{2}{*}{ Tumor growth pattern ${ }^{b}$} & Expansive & 82 & $16(19.5 \%)$ & $28(34.1 \%)$ & $38(46.3 \%)$ \\
\hline & Infiltrative & 33 & $1(3.0 \%)$ & $10(30.3 \%)$ & $22(66.7 \%)$ \\
\hline \multirow[t]{3}{*}{ Desmoplastic stromal reaction } & Slight & 40 & $8(20.0 \%)$ & $15(37.5 \%)$ & $17(42.5 \%)$ \\
\hline & Moderate & 51 & $6(11.8 \%)$ & $18(35.3 \%)$ & 27 (52.9\%) \\
\hline & Extensive & 24 & $3(12.5 \%)$ & $5(20.8 \%)$ & $16(66.7 \%)$ \\
\hline \multirow[t]{2}{*}{ Crohn's-like lymphoid reaction } & Inconspicuous & 89 & $13(14.6 \%)$ & $28(31.5 \%)$ & 48 (53.9\%) \\
\hline & Conspicuous & 26 & $4(15.4 \%)$ & $10(38.5 \%)$ & $12(46.2 \%)$ \\
\hline \multirow[t]{2}{*}{ Lymphatic invasion $^{b}$} & Absent & 62 & $14(22.6 \%)$ & $20(32.3 \%)$ & $28(45.2 \%)$ \\
\hline & Present & 53 & $3(5.7 \%)$ & $18(34.0 \%)$ & $32(60.4 \%)$ \\
\hline \multirow[t]{2}{*}{ Venous invasion $^{b}$} & Absent & 74 & $14(18.9 \%)$ & $26(35.1 \%)$ & $34(45.9 \%)$ \\
\hline & Present & 41 & $3(7.3 \%)$ & $12(29.3 \%)$ & $26(63.4 \%)$ \\
\hline \multirow[t]{2}{*}{ Neural invasion ${ }^{b}$} & Absent & 93 & $14(15.1 \%)$ & $36(38.7 \%)$ & $43(46.2 \%)$ \\
\hline & Present & 22 & $3(13.6 \%)$ & $2(9.1 \%)$ & $17(77.3 \%)$ \\
\hline \multirow[t]{2}{*}{ Lymph node metastasis $^{c}$} & Absent & 68 & $13(19.1 \%)$ & $27(39.7 \%)$ & $28(41.2 \%)$ \\
\hline & Present & 47 & $4(8.5 \%)$ & $11(23.4 \%)$ & $32(68.1 \%)$ \\
\hline \multirow[t]{2}{*}{ Hepatic metastasis ${ }^{b}$} & Absent & 101 & $16(15.8 \%)$ & $36(35.6 \%)$ & $49(48.5 \%)$ \\
\hline & Present & 14 & $1(7.1 \%)$ & $2(14.3 \%)$ & $11(78.6 \%)$ \\
\hline \multirow[t]{5}{*}{ Dukes' classification $^{a}$} & A & 42 & $10(23.8 \%)$ & $16(38.1 \%)$ & $16(38.1 \%)$ \\
\hline & $\mathrm{B}$ & 22 & $3(13.6 \%)$ & $9(40.9 \%)$ & $10(45.5 \%)$ \\
\hline & $\mathrm{C} 1$ & 19 & $2(10.5 \%)$ & $6(31.6 \%)$ & $11(57.9 \%)$ \\
\hline & $\mathrm{C} 2$ & 11 & $0(0.0 \%)$ & $4(36.4 \%)$ & $7(63.6 \%)$ \\
\hline & $\mathrm{D}$ & 21 & $2(9.5 \%)$ & $3(14.3 \%)$ & $16(76.2 \%)$ \\
\hline Totals & & 115 & $17(14.8 \%)$ & $38(33.0 \%)$ & $60(52.2 \%)$ \\
\hline
\end{tabular}

${ }^{a} P<.05$, Kruskal-Wallis test.

${ }^{b} P<.05$, Mann-Whitney's $U$ test.

${ }^{c} P<.005$, Mann-Whitney's $U$ test.

classification (20, 21). However, the mechanism of invasion and metastasis of colorectal carcinoma has not been fully elucidated.

In our study, MMP-1 was not expressed either in normal colon epithelium or in colorectal adenomas. MMP-1 immunoreactivity was weak in intramucosal carcinomas (Tis), but it was enhanced in invasive carcinomas (T1-4). These findings suggest that MMP-1 is over-expressed from an early stage of tumor invasion when carcinoma cells have invaded beyond the muscularis mucosa. Among the invasive carcinomas, MMP-1 immunoreactivity was significantly correlated with the depth grading of tumor invasion and the degree of MMP-1 expression was higher in the cases showing an infiltrative growth pattern than the cases showing an expansive pattern. Van der Stappen et al. (32) have shown that raised collagenolytic activity against collagens of types I and III in carcinoma tissue extract was associated with deeper invasion of colorectal carcinoma. The main structural components of the stroma in the gastrointestinal tract are collagens of types I and III $(33,34)$. Carcinoma cells must break down these structural components for further invasion through the bowel wall; such degradation is effected mainly by MMP-1 (4). Thus, overexpres- sion of MMP-1 is considered to play a key role in the process of local tumor invasion. Our results support this contention and indicate that MMP-1 expression by tumor cells is closely involved in the facilitation of local invasion in colorectal carcinoma.

Metastatic spread of tumor cells involves invasion into lymphatic and blood vessels and this process requires degradation of the basement membrane surrounding these vessels. Thus, much attention has focused on the gelatinases (MMP-2 and MMP-9) and stromelysins (MMP-3 and MMP-7, especially), which specifically degrade the basement membrane $(35,36)$. In our results, the cases showing strong immunoreaction for MMP-1 in the primary lesion are likely to have metastases to the lymph nodes or liver. The control of MMPs is a multistep process. The MMP gene is primarily regulated at the transcriptional level. Regulation is associated with several cytokines, growth factors, and with the combination of oncogenes (3). For example, the proto-oncogene Ets- 1 is a transcription factor known to enhance the activity of MMP-1, MMP-3, and MMP-9. We have demonstrated Ets-1 overexpression in relationship to tumor invasion and metastasis in gastric cancer (24). 

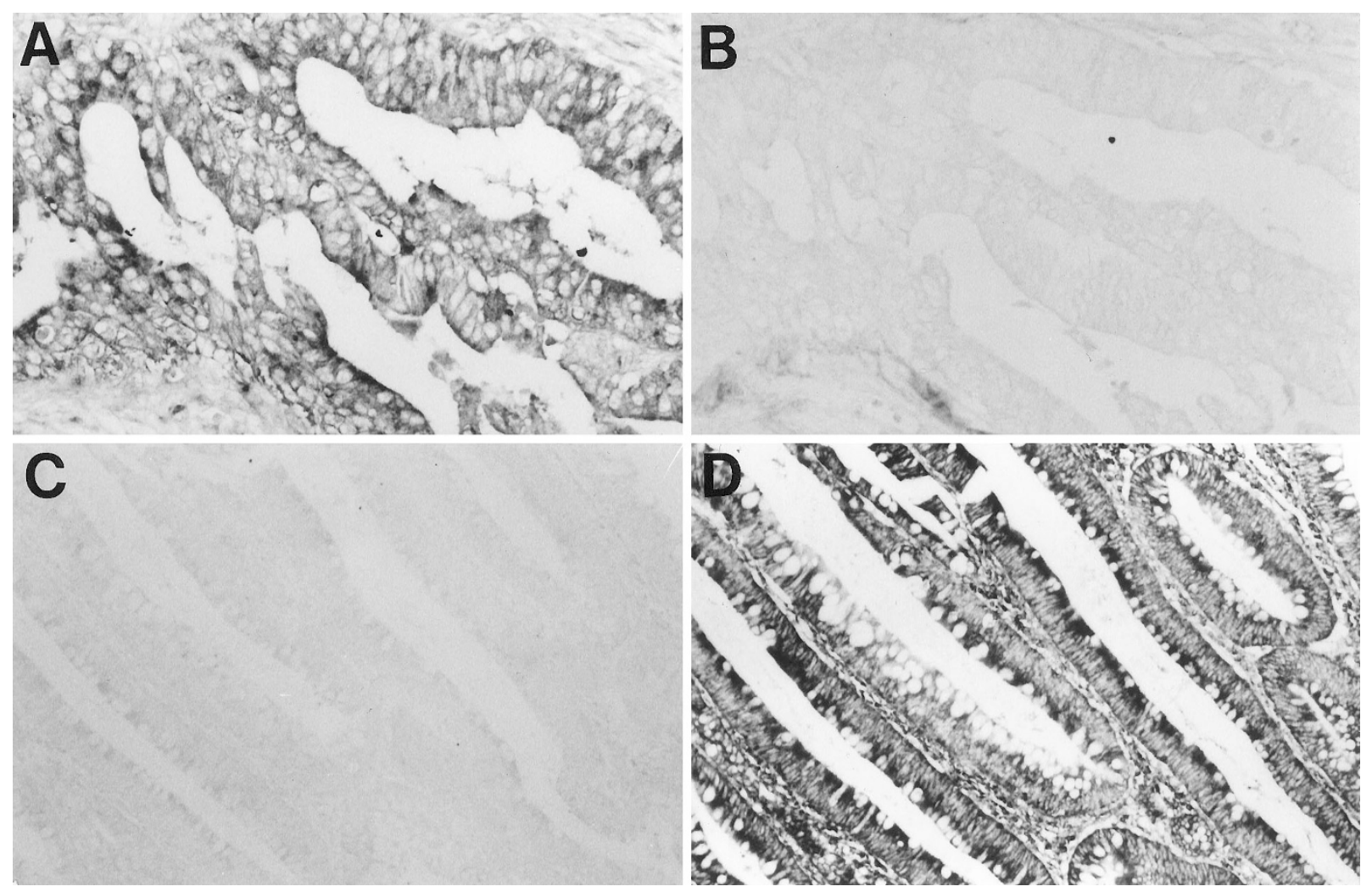

FIGURE 2. In situ hybridization of $M M P-1 \mathrm{mRNA}$ in colorectal adenocarcinoma and adenoma. $M M P-1 \mathrm{mRNA}$ was detected in the cytoplasm of carcinoma cells (A) (immunoalkaline phosphatase stain; original magnification, $50 \times$ ). The sense labeled probe showed no specific hybridization signals (B) (immunoalkaline phosphatase stain; original magnification, 50 $\times$ ). MMP-1 mRNA was not detected in adenoma (C) (immunoalkaline phosphatase stain; original magnification, $25 \times$ ). In situ hybridization of human $28 \mathrm{~S}$ ribosome RNA, used as a technical control, showed strongly positive expression (D) (immunoalkaline phosphatase stain; original magnification, $25 \times$ ).

A

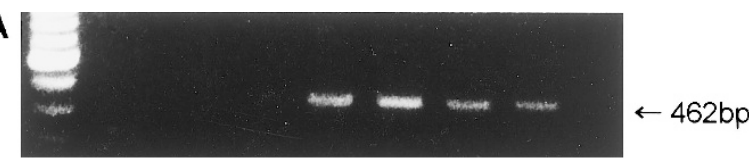

B

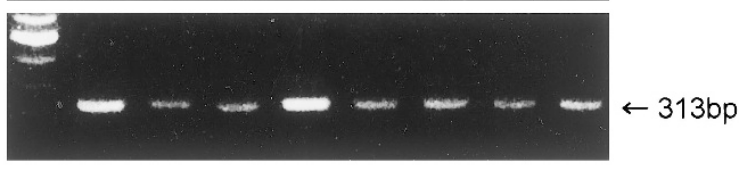

$\begin{array}{lllllllll}M & 1 & 2 & 3 & 4 & 5 & 6 & 7 & 8\end{array}$

FIGURE 3. RT-PCR analysis of $M M P-1$ mRNA expression using the specific primer pairs predicted to amplify the fragment sizes given on the right (A: MMP-1; B: $\beta$-actin as an internal control). Total RNA was prepared from normal colorectal mucosa (lane 1-2), colon adenoma tissue (lane 3), human colorectal adenocarcinoma tissue (lane 4-5) and carcinoma cell lines (lane 6, LoVo; lane 7, SW837; lane 8, DLD-1). Size makers (lane $\boldsymbol{M}$ ) consist of 100-bp DNA ladder makers (Takara, Tokyo, Japan).

Most MMPs are secreted as latent precursors that are proteolytically activated in the extracellular space (3). It has been reported that a family of MMPs is activated synergistically with enzymatic cooperation and works to facilitate metastasis (37). On the other hand, in our study, the incidence of lymph node metastasis and liver metastasis increased with the depth of tumor invasion (data not shown). The further correlation with Dukes' classification and with these two parameters, however, may simply be derived from the inclusion of cases with deeper invasion and not represent a separate and distinct correlation. The enzymatic activity of MMPs has been considered to be specifically inhibited by tissue inhibitor of metalloproteinases (TIMPs). However, a recent study has shown that high levels at least of TIMP-1 and TIMP-2 are associated with aggressive cancers (38). Although the MMPs in malignant tumors have been extensively studied, their specific role in the progression of tumor may be more complex than has been assumed. Further investigations are required to establish the details.

Poorly differentiated adenocarcinomas show invasive spreading histologically and have a significantly poorer prognosis than well and moderately differentiated carcinomas (39). It has been reported that there was a significant correlation between the grade of histologic differentiation and collagenolytic activity (32). However, our results indicated no association between MMP-1 expression and tumor differentiation.

Tumor desmoplasia is a common feature in several malignant human tumors. It has been reported that a well-marked desmoplastic stromal reaction is associated with a poorer prognosis (40). Expression of MMP-1 has been observed in areas of rapid ex- 
tracellular matrix remodeling both in physiologic and pathologic situations (2). Graham and Appelman (17) noted the potential prognostic significance of another immune host response to invasive colorectal carcinoma characterized by discrete lymphoid aggregates in the muscularis propria or pericolic fibroadipose tissue in a pattern termed the Crohn's-like lymphoid reaction. In our study, there were no significant associations between MMP-1 immunoreactivity in carcinoma cells and the degree of desmoplastic stromal reaction or Crohn'slike lymphoid reaction.

One of the intriguing questions concerning MMP-1 expression is the cellular source of this enzyme. Our study showed that MMP-1 is immunolocalized in carcinoma cells as well as stromal cells in colorectal carcinoma. Although previous investigators had described that MMP-1 was expressed mainly in stromal cells surrounding the carcinoma cells, recent studies have reported MMP-1 immunophenotypic expression also in carcinoma cells themselves and suggested the possibility of production of MMP-1 by these cells (10-13). Nomura et al. (10), using the same monoclonal antibody that we used in this study, reported that MMP-1 expression in carcinoma cells was present in $83 \%$ of gastric cancers. The differences in tissue localization of MMP-1 expression reported in earlier studies compared with this and the present study may therefore be due to the use of different antibodies. In previous studies, $M M P-1$ mRNA has been documented in stromal cells surrounding the tumor, but not in carcinoma cells $(41,42)$. In the present study, however, the expression of MMP-1 mRNA was detected by in situ hybridization in the colorectal carcinoma cells themselves as well as in the stromal cells. We have also previously reported the expression of the $M M P-1$ gene in pancreatic adenocarcinoma cells (43). The oligonucleotide probe used in this study was sufficiently stringent to discriminate between other known sequences, including mRNA for other types of MMPs, by sequence data base analysis. RT-PCR of the MMP-1 mRNA from the human colorectal carcinoma cell lines confirmed the transcription of $M M P-1$ mRNA in carcinoma cells.

In conclusion, our findings suggest that MMP-1 expression by the carcinoma cells themselves is one of the important factors related to local tumor invasion and metastasis of colorectal cancer.

Acknowledgments: The authors wish to thank Dr. Arifumi Akashi (Department of Cell Physiology, Nagasaki University, Japan) and Dr. Akio Kawaguchi (Department of Surgery, Inoue Hospital, Japan) for their kind assistance.

\section{REFERENCES}

1. Liotta LA. Tumor invasion and metastasis: role of extracellular matrix. Cancer Res 1986;46:1-7.

2. Matrisian LM. Metalloproteinases and their inhibitors in matrix remodeling. Trends Genet 1990;6:121-5.

3. Westermarck J, Kahari VM. Regulation of matrix metalloproteinase expression in tumor invasion. FASEB J 1999;13:78192.

4. Harris ED Jr, Krane SM. Collagenases (second of three parts). N Engl J Med 1974;291:605-9.

5. Ossowski L. Invasion of connective tissue by human carcinoma cell lines: requirement for urokinase, urokinase receptor, and interstitial collagenase. Cancer Res 1992;52:675460.

6. Bauer EA, Gordon JM, Reddick ME, Eisen AZ. Quantitation and immunocytochemical localization of human skin collagenase in basal cell carcinoma. J Invest Dermatol 1977;69: 363-7.

7. Huang CC, Blitzer A, Abramson M. Collagenase in human head and neck tumors and rat tumors and fibroblasts in monolayer cultures Ann Otol Rhinol Laryngol 1986;95:15861.

8. Bolon I, Gouyer V, Devouassoux M, Vandenbunder B, Wernert N, Moro D, et al. Expression of c-ets-1, collagenase 1, and urokinase-type plasminogen activator genes in lung carcinomas. Am J Pathol 1995;147:1298-310.

9. Hewitt RE, Leach IH, Powe DG, Clark IM, Cawston TE, Turner DR. Distribution of collagenase and tissue inhibitor of metalloproteinase (TIMP) in colorectal tumors. Int J Cancer 1991;49:666-72.

10. Nomura H, Fujimoto N, Seiki M, Mai M, Okada Y. Enhanced production of matrix metalloproteinases and activation of matrix metalloproteinase 2 (gelatinase A) in human gastric carcinomas. Int J Cancer 1996;69:9-16.

11. Murray GI, Duncan ME, O’Neil P, Melvin WT, Fothergill JE. Matrix metalloproteinase- 1 is associated with poor prognosis in colorectal cancer. Nat Med 1996;2:461-2.

12. Murray GI, Duncan ME, Arbuckle E, Melvin WT, Fothergill JE. Matrix metalloproteinases and their inhibitors in gastric cancer. Gut 1998;43:791-7.

13. Nakopoulou L, Giannopoulou I, Gakiopoulou H, Liapis H, Tzonou A, Davaris PS. Matrix metalloproteinase- 1 and -3 in breast cancer: correlation with progesterone receptors and other clinicopathologic features. Hum Pathol 1999;30:43642.

14. Jass JR, Sobin LH, editors. Histological typing of intestinal tumors. World Health Organization. 2nd ed. Berlin, Germany: Springer-Verlag; 1989.

15. Beahrs OH, Henson DE, Hutter RVP, Kennedy BJ, editors. Manual for staging of cancer. 4th ed. Philadelphia: Lippincott; 1992. p. 69-73.

16. Jass JR, Atkin WS, Cuzick J, Bussey HJ, Morson BC, Northover $\mathrm{JM}$, et al. The grading of rectal cancer: historical perspectives and a multivariate analysis of 447 cases. Histopathology 1986;10:437-59.

17. Graham DM, Appelman HD. Crohn's-like lymphoid reaction and colorectal carcinoma: a potential histologic prognosticator. Mod Pathol 1990;3:332-5.

18. Seefeld PH, Bargen JA. The spread of cancer of the rectum: invasion of the lymphatics, veins and nerves. Ann Surg 1943; 118:76-89.

19. Talbot IC, Ritchie S, Leighton M, Hughes AO, Bussey HJR, Morson BC. Invasion of veins by carcinoma of rectum: methods of detection, histological features and significance. Histopathology 1981;5:141-63.

20. Dukes CE. The surgical pathology of rectal cancer. J Clin Pathol 1949;2:95-8. 
21. Whittaker M, Goligher JC. The prognosis after surgical treatment for carcinoma of the rectum. Br J Surg 1976;63:384-8.

22. Okada Y, Gonoji Y, Nakanishi I, Nagase H, Hayakawa T. Immunohistochemical demonstration of collagenase and tissue inhibitor of metalloproteinases (TIMP) in synovial lining cells of rheumatoid synovium. Virchows Arch B Cell Pathol Incl Mol Pathol 1990;59:305-12.

23. Templeton NS, Brown PD, Levy AT, Margulies IM, Liotta LA, Stetler-Stevenson WG. Cloning and characterization of human tumor cell interstitial collagenase. Cancer Res 1990;50: 5431-7.

24. Nakayama T, Ito M, Ohtsuru A, Naito S, Nakashima M, Fagin JA, et al. Expression of the Ets-1 proto-oncogene in human gastric carcinoma: correlation with tumor invasion. Am J Pathol 1996;149:1931-9.

25. Yoshii A, Koji T, Ohsawa N, Nakane PK. In situ localization of ribosomal RNAs is a reliable reference for hybridizable RNA in tissue sections. J Histochem Cytochem 1995;43:321-7.

26. Gravallese EM, Darling JM, Ladd AL, Katz JN, Glimcher LH. In situ hybridization studies of stromelysin and collagenase messenger RNA expression in rheumatoid synovium. Arthritis Rheum 1991;34:1076-84.

27. Chomczynski P, Sacchi N. Single-step method of RNA isolation by acid guanidinium thiocyanate-phenol-chloroform extraction. Anal Biochem 1987;162:156-9.

28. Drewinko B, Romsdahl MM, Yang LY, Ahearn MJ, Trujillo JM. Establishment of a human carcinoembryonic antigenproducing colon adenocarcinoma cell line. Cancer Res 1976; 36:467-75.

29. Chen TR, Hay RJ, Macy ML. Karyotype consistency in human colorectal carcinoma cell lines established in vitro. Cancer Genet Cytogen 1982;6:93-117.

30. Trainer DL, Kline T, McCabe FL, Faucette LF, Feild J, Chaikin $\mathrm{M}$, et al. Biological characterization and oncogene expression in human colorectal carcinoma cell lines. Int J Cancer 1988;41:287-96.

31. Aiba T, Akeno N, Kawane T, Okamoto H, Horiuchi N. Matrix metalloproteinases-1 and -8 and TIMP-1 mRNA levels in normal and diseased human gingivae. Eur J Oral Sci 1996; 104:562-9.
32. van der Stappen JW, Hendriks T, Wobbes T. Correlation between collagenolytic activity and grade of histological differentiation in colorectal tumors. Int J Cancer 1990;45:1071-8.

33. Thomson HJ, Busuttil A, Eastwood MA, Smith AN, Elton RA. The submucosa of the human colon. J Ultrastruct Mol Struct Res 1986;96:22-30.

34. Hilska M, Collan Y, Peltonen J, Gullichsen R, Paajanen H, Laato M. The distribution of collagen types I, III, and IV in normal and malignant colorectal mucosa. Eur J Surg 1998; 164:457-64.

35. Liotta LA, Tryggvason K, Garbisa S, Hart I, Foltz CM, Shafie S. Metastatic potential correlates with enzymic degeneration of basement-membrane. Nature 1980;284:67-8.

36. Aznavoorian S, Murphy AN, Stetler-Stevenson WG, Liotta LA. Molecular aspects of tumor cell invasion and metastasis. Cancer 1993;71:1368-83.

37. Murphy G, Cockett MI, Stephens PE, Smith BJ, Docherty AJ. Stromelysin is an activator of procollagenase. A study with natural and recombinant enzymes. Biochem J 1987;248:265-8.

38. Gomez DE, Alonso DF, Yoshiji H, Thorgeirsson UP. Tissue inhibitors of metalloproteinases: structure, regulation and biological functions. Eur J Cell Biol 1997;74:111-22.

39. Newland RC, Chapuis PH, Pheils MT, MacPherson JG. The relationship of survival to staging and grading of colorectal carcinoma: a prospective study of 503 cases. Cancer 1981; 47:1424-9.

40. Halvorsen TB, Seim E. Association between invasiveness, inflammatory reaction, desmoplasia and survival in colorectal cancer. J Clin Pathol 1989;42:162-6.

41. Steven TG, Kankatsu T, Tadashi M, Yvonne MK. Intestinal collagenase gene expression in colonic neoplasia. Am J Pathol 1993;143:663-71.

42. Otani Y, Okazaki I, Arai M, Kameyama K, Wada N, Maruyama $\mathrm{K}$, et al. Gene expression of interstitial collagenase (matrix metalloproteinase 1) in gastrointestinal tract cancers. J Gastroenterol 1994;29:391-7.

43. Ito T, Ito M, Shiozawa J, Naito S, Kanematsu T, Sekine I. Expression of the MMP-1 in human pancreatic carcinoma: relationship with prognostic factor. Mod Pathol 1999;12:66974 . 